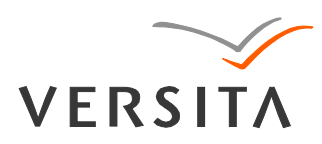

GEOCHRONOMETRIA 41(1) 2014: 92-103

DOI 10.2478/s13386-013-0137-2

Available online at

www.springerlink.com

\title{
OAK DECLINE IN A SOUTHERN FINNISH FOREST AS AFFECTED BY A DROUGHT SEQUENCE
}

\author{
KRISTINA SOHAR ${ }^{1}$, SAMULI HELAMA ${ }^{2}$, ALAR LÄÄNELAID ${ }^{1}$, \\ JUHA RAISIO ${ }^{3}$ and HEIKKI TUOMENVIRTA ${ }^{4}$ \\ ${ }^{I}$ Department of Geography, Institute of Ecology and Earth Sciences, University of Tartu, Vanemuise 46, 51014 Tartu, Estonia \\ ${ }^{2}$ Finnish Forest Research Institute, Northern Unit, P.O. Box 16, 96301 Rovaniemi, Finland \\ ${ }^{3}$ The City of Helsinki, The Public Works Department, Street and Park Division, P.O. Box 1515, 00099 Helsinki, Finland \\ ${ }^{4}$ Finnish Meteorological Institute, P.O. Box 503, 00101 Helsinki, Finland
}

Received 28 March 2013

Accepted 21 August 2013

\begin{abstract}
We investigated the decline of a pedunculate oak (Quercus robur L.) forest growing on shallow soil at the northern distributional limit of the species in southern Finland, using the dendroclimatic approach. About 200-year-old trees in three vigour classes - healthy, declining and dead were sampled in 2008. Annual tree-ring, earlywood and latewood widths were measured and chronologies were established. The tree-ring data were correlated with monthly and seasonal climate data. Radial increment of oaks was positively related to the June and July precipitations. This was expressed especially in total ring width and latewood width, whereas the earlywood was more influenced by the warmer winter and spring. Furthermore, the correlation between the current year earlywood width and the preceding year latewood width was higher than between the earlywood and latewood of the same year. The analyses showed that the dead oaks and part of the declining oaks had ceased growing during 2005-2007 after a decade-long summer drought series. This indicates a time lag in the oak dieback. The radial growth of the declining and the dead oaks had dropped already since the 1990s, while the healthy oaks had better long-term growth and higher adaptive capacity to climate variation.
\end{abstract}

Keywords: dendroclimatology, mortality, tree rings, earlywood, latewood, Quercus robur L.

\section{INTRODUCTION}

Forest mortality has been reported worldwide recently and has been attributed to climate change-related drought and heat stress (Allen et al., 2010). Besides, several studies have shown a large-scale decline of Quercus species throughout Europe (e.g. Führer, 1998; Siwecki and Ufnalski, 1998; Sonesson, 1999; Peñuelas et al., 2001; Landmann and Dreyer, 2006; Drobyshev et al., 2007a, 2007b) as well as in North America (e.g. Starkley and

Corresponding author: K. Sohar

e-mail: kristina.sohar@ut.ee
Oak, 1989; Starkley et al., 1989; Faber-Langendoen and Tester, 1993; Starkley et al., 2004, Catton et al., 2007). As this extensive mortality causes concern for foresters, recreation managers as well as to the wider community, there is an interest and demand to search for the reasons. According to McCracken (1985) three concepts of oak dieback can be distinguished: (1) single causal factors (like an extreme weather event or a pathogen), (2) cohort senescence (combination of age and environmental stress), and (3) decline syndrome complex. The latter involves long-term predisposing factors like tree age, climate and soil conditions, and long-term contributing 
factors such as pathogens, as well as short-term inciting factors like a single extreme weather or air-pollution event (Manion, 1981). Thus, the reasons are related with several biotic and abiotic factors, and are frequently a combination of different severe determinants (e.g. Wargo, 1996; Gibbs and Greig, 1997; Thomas et al., 2002), partly with site-specific causes (Jung et al., 2000; Jönsson et al., 2005).

Although oaks have both morphological and physiological adaptations to tolerate drought (e.g. deep rooting, control of stomatal conductance, non-stomatal control of carbon fixation) (Dickson and Tomlinson, 1996), these reactions lose importance with increasing drought stress making trees more susceptible to other stress factors (Thomas et al., 2002). It has been shown that experimentally applied drought reduces stem and shoot growth, and whole-tree leaf area (Arend et al., 2011) while moderate climate change does not affect neither leaf nitrogen nor nonstructural carbohydrates (Li et al., 2013). All that considered, drought has been assumed to be one of the main factors causing oak decline through reduction of water uptake (e.g. Siwecki and Ufnalski, 1998; Drobyshev et al., 2007b) or weakening the trees against other stress determinants like pathogenic fungi (e.g. mildew) and insect pests (e.g. leaf roller). All this results in defoliation which leads to the reduction of photosynthesis and to death (e.g. Siwecki and Ufnalski, 1998; Thomas et al., 2002).

It is well known that trees provide information on the past growing conditions in their annual rings, and different parameters of the latter can be easily measured as a continuous sequence of years and directly calibrated against any predisposing environmental time series, for example climatic records (Fritts, 1976). Dendrochronological techniques allow us to extract external or internal growth signals from the overall growth variability (Cook, 1987) and to determine the relative importance of an environmental factor (e.g. a weather variable) to tree vigour. A tree-ring width archive can be used in explaining mortality retrospectively, for example, identifying the presence and spatiotemporal patterns of pre-mortem growth depressions and dating the exact time of death (Drobyshev et al., 2007b). The dendrochronological data can be used for predicting the time of tree death as well (Pedersen, 1998; Cherubini et al., 2002; Bigler and Bugmann, 2004; Dobbertin, 2005).

A decline in pedunculate oaks (Quercus robur L.) as well as other tree species has been observed in the Helsinki metropolitan area in Finland during the recent years, especially 2003 (Ympäristöraportoinnin asiantuntijatyöryhmä, 2004; Holopainen et al., 2006). Finnish oaks grow at the species' northernmost natural regeneration border (e.g. Axelrod, 1983; Dahl, 1998). Cold hardiness during the autumn is considered as a main factor limiting oak seedling to spread further north (Repo et al., 2008), combined with the destruction by humans and the competition with spruce (Rainio, 1977). On the other hand, dendroclimatological analyses have revealed that radial growth is controlled especially by summer rainfall, and mortality has been associated with droughts, likewise with shallow soil depth, which increase environmental tree stress (Helama et al., 2009).

Our work is a part of a wider research on oak mortality in Finland, and therefore it follows similar study design and the methods used before (Helama et al., 2009). The goal was to determine the temporal mortality pattern and to examine the decline of pedunculate oaks in the Tammisto forest using long-term tree-ring series (earlywood, latewood and total annual ring width) in connection with climatic and soil data.

\section{MATERIAL AND METHODS}

\section{Tree-ring data}

The Tammisto Park is a 15.5 ha nature reserve of natural forest located in Vantaa, Helsinki metropolitan area $\left(60^{\circ} 16^{\prime} 35^{\prime \prime}\right.$, $2^{\circ} 57^{\prime} 49^{\prime \prime}$ E; Fig. 1). A sporadically exposed bedrock ridge makes up the centre of the area, up to $38 \mathrm{~m}$ above sea level, and is covered by Pinus sylvestris. The northern slope is dominated by Picea abies while the southern side is covered by broadleaf forest. In addition to Quercus robur, Tilia cordata and Acer platanoides are found while the understory is occupied by Corylus avellana. Spruce overgrowth is stopped by the protection activities (Honkanen, 2009).

We had a permission to core not more than 30 pedunculate oaks for this study in July 2008. Following the criteria used earlier (Helama et al., 2009), ten healthy trees defined as living trees with green foliage, ten declining trees as diagnosed by reduced crown condition, mod-

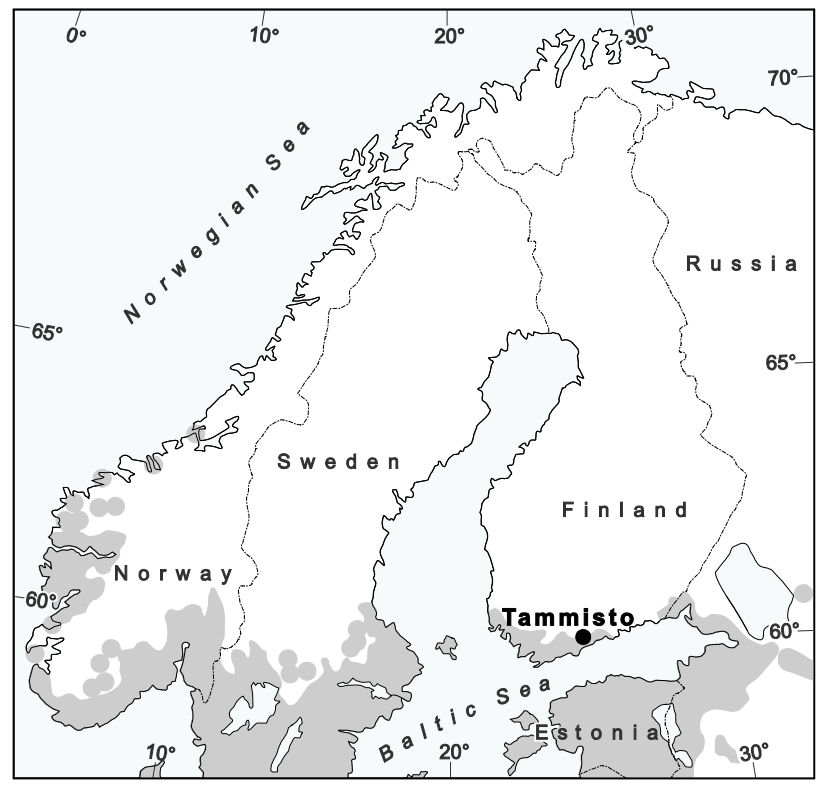

Fig. 1. Location of the study site. Distribution of oak in grey (EUFORGEN, 2009). 
est foliage degeneration and/or some branch death, and ten dead trees diagnosed by defoliation and overall branch death were randomly chosen. We took tree-ring samples with an increment borer from breast height towards the pith from the northern side of the trunk and surveyed the soil depth by driving a soil probe into the ground until refusal (Tesfa et al., 2009) at locations selected from four directions at a distance of two meters from the stem. The arithmetic mean of the four observations, and the shallowest observation as minimum soil depth, were used in the data analysis.

Within the tree rings we measured the early- and latewood widths separately to the nearest $1 / 100 \mathrm{~mm}$ using a Lintab ${ }^{\text {TM }}$ measuring table (Heidelberg, Germany) equipped with a light microscope. We distinguished the boundary between the earlywood and latewood according to a qualitative aspect: the earlywood contains the large vessel zone, while the latewood comprises the small pore zone (e.g. Schweingruber, 2007). The sum of the earlyand latewood measurements was adopted as the total annual tree-ring width. The TSAP-Win software (Rinn, 2003) was used to record the measured values and plot the graphs. The quality control of the series was performed visually from the graphs and with the Cofecha software from the Dendrochronology Program Library (Holmes, 1983). As the date of coring was known, the last annual ring of healthy oaks could be coupled with the calendar year 2008. The rest of the samples were crossdated against the mean chronology of healthy oaks using the dendrochronological program CATRAS (Aniol, 1983 ) and the dating results were checked visually from the graphs. This cross-dating resulted with the calendar years for all earlywood, latewood, and annual ring widths.

\section{Dendrochronological analysis}

Average series of earlywood, latewood, and annual ring widths were created from each vigour class according to the cambial age (e.g. Briffa et al., 1992) where the rings were aligned by their age starting from the pith instead of the calendar years at breast height. Although there were only two cores containing the pith, the majority of the cores still had near-pith tree rings according to the curved innermost ring shape (on average, six innermost missing rings per core according to a pith indicator template). Only one tree had a too large diameter for catching the pith and one tree was rotten inside. The relative growth rate (RGR) (Briffa and Melvin, 2011; Helama et al., 2012) for each tree was calculated as

$$
R G R=\sum_{t=1}^{n} x_{t} / \sum_{t=1}^{n} \bar{x}_{t}
$$

where $x_{t}$ is the tree-ring width in year $t, \bar{x}_{t}$ is the mean width of all rings in year $t$, and $n$ is the number of rings in the series. Thus, it is a ratio of the tree radius at its final year to the average overall-sample radius at that year. The RGR values were averaged across each vigour class.

As follows, we adopted a standardization procedure (Fritts, 1976) and converted the measurement series into dimensionless indices. To remove the tree-age-related growth trend and to reduce non-climatic noise (i.e. lowfrequency noise), the measurement series were detrended using a stiff spline function, which preserves $50 \%$ of the variance contained in two-thirds of the individual series length (Cook and Peters, 1981). The spline curve was fitted and the indices derived from the curve as ratios using the Arstan program (Cook, 1985).

In order to compare the tree growth variability with the soil data, the standard deviation, the mean sensitivity (MS), and the first-order autocorrelation of each index series were computed by the Arstan program. While the standard deviation describes the total variation in the series, the mean sensitivity indicates the year-to-year variability between the adjacent ring widths and can be determined as

$$
M S=\frac{1}{n-1} \sum_{t=1}^{t=n-1}\left|\frac{2\left(x_{t+1}-x_{t}\right)}{x_{t+1}+x_{t}}\right|
$$

where $x_{t}$ is the tree-ring width in year $t$, and $n$ is the number of years/tree-rings in the series (Fritts, 1976). Also, we compared the RGR of each tree with the minimum soil depth data. As all these variables were normally distributed, we used the Pearson correlation coefficient (r) to describe their relationships.

\section{Dendroclimatologial analysis}

For the dendroclimatological analysis, the index series were pre-whitened in the Arstan to remove the persistence due to autocorrelation. The index series were averaged using a bi-weight robust mean estimation to reduce outlier effects (Cook, 1985). As a result, we received nine residual chronologies according to the three wood types and the three vigour classes. These chronologies were used for calculating the cross-correlations and for the dendroclimatological analysis. In addition, we correlated the earlywood width chronology with the latewood width chronology of the preceding year. The common period 1894-2004 was used for all chronologies. This time range contained at least five trees in each vigour class (Läänelaid, 2000).

We compared our standardised tree-ring data with monthly mean temperatures and precipitation sums from the Helsinki Kaisaniemi weather station $\left(60^{\circ} 10^{\prime} 48^{\prime \prime} \mathrm{N}\right.$, $24^{\circ} 56^{\prime} 24^{\prime \prime} \mathrm{E}, 4 \mathrm{~m}$ a.s.l.), located ca. $11 \mathrm{~km}$ from Tammisto. We used homogenised and detrended monthly records (Tuomenvirta, 2004) and the DendroClim2002 program (Biondi and Waikul, 2004) to examine the relationships between the tree-ring data and the meteorological variables. This process uses bootstrapped confidence intervals to estimate the significance $(p<0.05)$ of the response 
function coefficients, which are multivariate estimates from a principal component regression model (Briffa and Cook, 1990). Here we used the 12-month window from the previous year's October to the current year's September. Three-monthly seasonal average temperatures and precipitation sums from the previous September to the concurrent August were calculated and correlated with the tree-ring chronologies.

\section{RESULTS}

\section{Age and death dates of trees}

Altogether, we measured and dated 30 oak trees equally distributed between the three vigour classes. The dendrochronological statistics for the raw data as well as for the standardized chronologies by vigour class are summarised in Table 1. The sample size is shown in Fig. 2. Comparing the vigour classes, the declining oaks covered the longest time period (1799-2008) while the dead and the healthy oaks covered 1812-2006 and 1836-2008, respectively. However, according to the t-test, mean tree age did not differ significantly between the vigour classes $(p>0.05)$, as well as mean annual ring width, standard deviation, mean sensitivity and autocorrelation. Thus, according to the statistics there is no relevant difference between vigour classes. The oaks diagnosed as healthy were found forming the ring in the sampling year 2008. Among the declining oaks, five trees were found still growing in the summer of 2008 (two of them having only earlywood). The outermost parts of two trees were damaged (dated as 1950 and 1988), and two trees had formed their last ring in year 2006 and one in 2007, at least in the northern part of the stem. Among the dead trees, four oaks had stopped growing in the year 2006 and one in the year 2005 (three of them having only earlywood), the other five had damaged outermost rings and these were dated as 1976, 1989, 1991, 1992 and 1993.

\section{Tree-ring growth}

The average tree-ring series of the declining and the dead trees revealed clear pre-mortem growth reduction during the last decades in all ring width parameters (Fig. 2). For example, the mean annual ring widths differed significantly between the two periods ( $t$-test, $p<0.05$ ) being 1.3 and $1.2 \mathrm{~mm}$ for the declining and the dead trees, respectively, during the period 1973-1990, and 0.8 and $0.7 \mathrm{~mm}$, respectively, during the period 1991-2008. At the same time the healthy oaks had also a significant but still lower growth reduction (a difference $0.3 \mathrm{~mm}$ between two periods). The lower increment at the healthy oaks' early lifetime was caused by the exceptionally small sample replication (only one tree). The latewood and the annual ring width cambial growth pattern (Fig. 3) showed that the healthy and the dead trees had similar

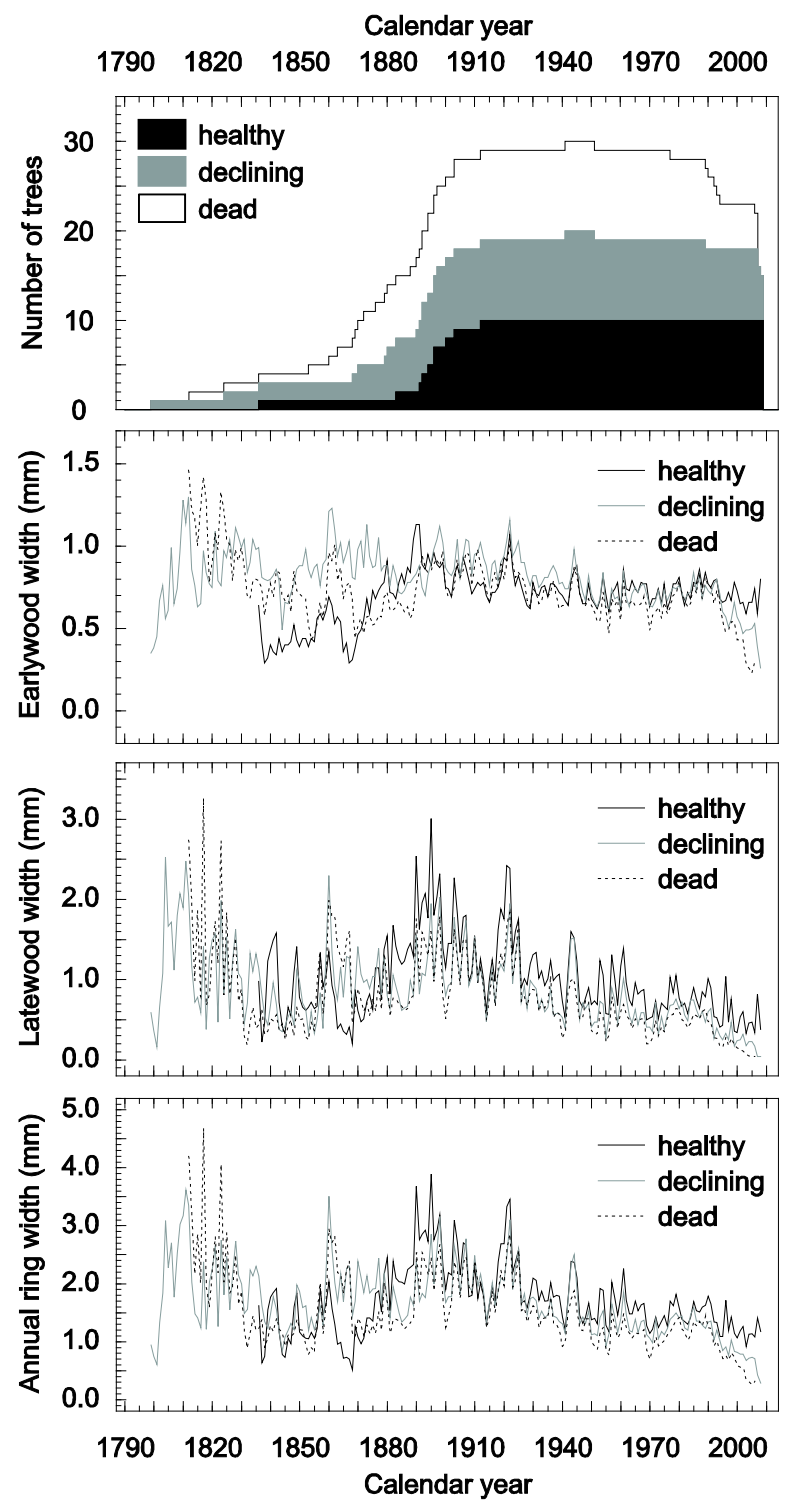

Fig. 2. Annual sample replication and average earlywood, latewood, and total annual ring width series by vigour class.

Table 1. Statistics on the tree-ring measurements and on the indexed chronology.

\begin{tabular}{l|ccccc|ccc}
\hline \multirow{2}{*}{$\begin{array}{l}\text { Vigour } \\
\text { class }\end{array}$} & $\begin{array}{c}\text { Mean number } \\
\text { of years }\end{array}$ & $\begin{array}{c}\text { Mean ring } \\
\text { width }(\mathbf{m m})\end{array}$ & $\begin{array}{c}\text { Std. deviation } \\
(\mathbf{m m})\end{array}$ & $\begin{array}{c}\text { Mean } \\
\text { sensitivity }\end{array}$ & $\begin{array}{c}\text { 1st order auto- } \\
\text { correlation }\end{array}$ & $\begin{array}{c}\text { Std. deviation } \\
\begin{array}{c}\text { Mean } \\
\text { sensitivity }\end{array}\end{array} \begin{array}{c}\text { 1st order auto- } \\
\text { correlation }\end{array}$ \\
\hline Healthy & 118 & 1.77 & 0.77 & 0.21 & 0.73 & 0.16 & 0.18 & 0.02 \\
Declining & 126 & 1.60 & 0.73 & 0.23 & 0.69 & 0.23 & 0.24 & -0.07 \\
Dead & 129 & 1.52 & 0.73 & 0.22 & 0.74 & 0.22 & 0.21 & -0.03 \\
\hline
\end{tabular}


growth strategies over their lifespan; however the dead oaks had a lower relative growth rate (Eq. 2.1). The declining oaks appeared to have a slight growth recession

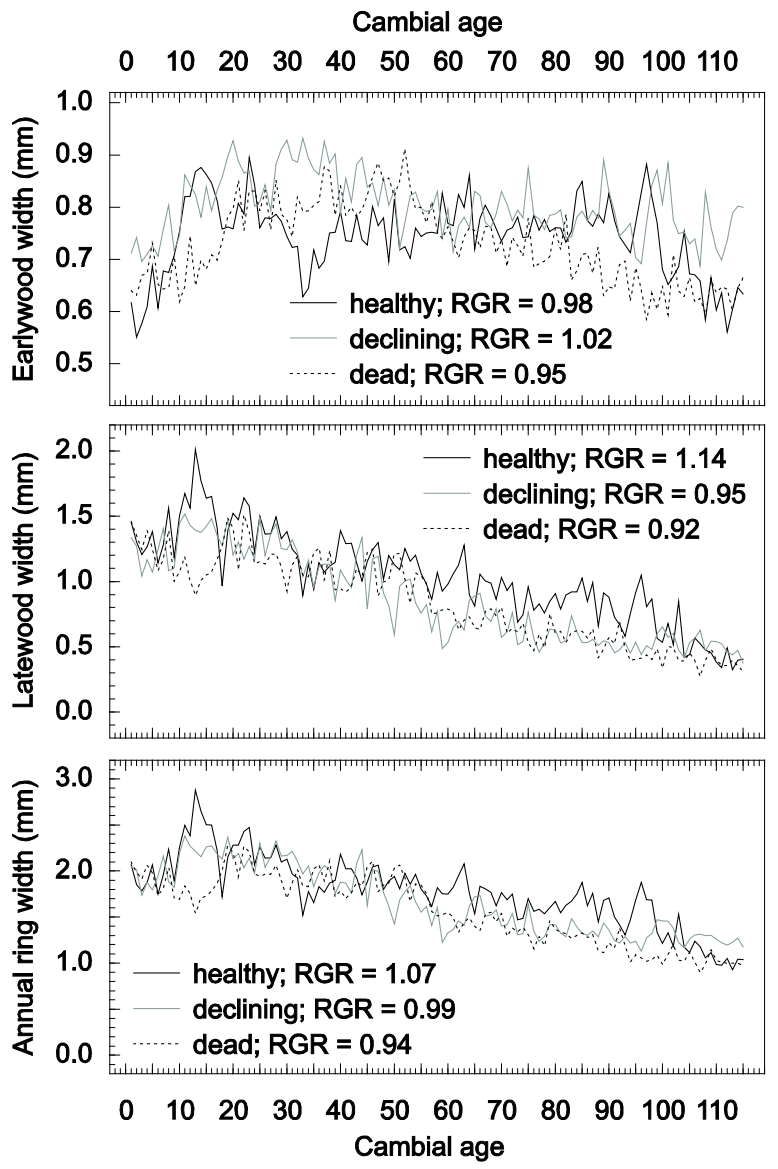

Fig. 3. Earlywood, latewood, and total annual ring width variability by vigour class during the 1-115 years cambial age being the common period that contains at least five series in each vigour class. Average relative growth rates (RGR) are calculated from individual tree characteristics across their entire lifespan. during the middle of their lifetime. The cambial growth patterns of earlywood series seemed to have a more heterogeneous within the vigour classes with a decrease in the second half of the dead trees' increment becoming distinguishable. The healthy trees' growth decline at their age 30-40 was caused by the similar age of most trees wherefore the effect of adverse calendar years was not smoothed out from the time series. Overall, according to the t-test, the differences in the relative growth rates between the nine subsets were not statistically significant $(\mathrm{p}>0.05)$.

The correlations between the pre-whitened chronologies (data from the same year) were positive and statistically significant ( $\mathrm{p}<0.05$; Table 2 ). However, the correlations within the earlywood chronologies were lower than within the latewood and the total ring width subsets. In addition, the similarity between the earlywood width of the current year and the latewood width of the preceding year was higher than between the latewood and earlywood widths of the same year in each vigour class, especially within the healthy trees. The correlations between the earlywood width and the total ring width chronologies were remarkably lower than between the latewood width and the total ring width chronologies. Thus, latewood width was more relevant in determining the annual ring width than earlywood width, which varied less between the years (Fig. 2).

\section{Tree-ring width and soil relationships}

Mean soil depth ranged between 29-66 cm, 28-66 cm, and $29-86 \mathrm{~cm}$ around the healthy, the declining, and the dead trees, respectively. The shallowest soil observations ranged between $8-44 \mathrm{~cm}$ around both the healthy and the declining oaks, and $14-76 \mathrm{~cm}$ around the dead oaks. No statistically significant differences in soil measurements between the vigour classes were identified (t-test, $p>0.05$ ). Moreover, none of the correlations between the growth variabilities of annual ring width indices, the relative growth rate and minimum soil thickness around each

Table 2. Pearson correlation coefficients between the residual chronologies during 1894-2004: earlywood width (EW), latewood width (LW), preceding year's latewood width $(\mathrm{pLW})$, total annual ring width $(A R W)$ of healthy $(H E)$, declining $(D E)$, and dead $(D D)$ oaks. Statistically significant relationships $(p<0.05)$ are in bold.

\begin{tabular}{|c|c|c|c|c|c|c|c|c|c|c|c|c|}
\hline & $\mathrm{EW}_{\mathrm{HE}}$ & $E W_{D E}$ & $E W_{D D}$ & $\mathrm{LW}_{\mathrm{HE}}$ & $\mathrm{LW}_{\mathrm{DE}}$ & $\mathrm{LW}_{\mathrm{DD}}$ & $\mathrm{pLW}_{\mathrm{HE}}$ & $p L W_{D E}$ & $\mathrm{pLW} W_{\mathrm{DD}}$ & $\mathrm{ARW}_{\mathrm{HE}}$ & $\mathrm{ARW}_{\mathrm{DE}}$ & $\mathrm{ARW}_{\mathrm{DD}}$ \\
\hline$\overline{\text { EWHE }_{\text {HE }}}$ & - & & & & & & & & & & & \\
\hline$E W_{D E}$ & 0.69 & - & & & & & & & & & & \\
\hline EWDD & 0.71 & 0.74 & - & & & & & & & & & \\
\hline $\mathrm{LW}_{\mathrm{HE}}$ & 0.25 & 0.36 & 0.36 & - & & & & & & & & \\
\hline$L W_{D E}$ & 0.25 & 0.41 & 0.39 & 0.82 & - & & & & & & & \\
\hline$L W_{D D}$ & 0.27 & 0.43 & 0.39 & 0.85 & 0.82 & - & & & & & & \\
\hline pLW & 0.62 & 0.42 & 0.46 & 0.01 & 0.06 & 0.09 & - & & & & & \\
\hline pLWDE & 0.54 & 0.48 & 0.47 & -0.01 & 0.01 & 0.02 & 0.82 & - & & & & \\
\hline pLW & 0.57 & 0.44 & 0.50 & 0.03 & 0.11 & 0.11 & 0.85 & 0.83 & - & & & \\
\hline $\mathrm{ARW}_{\mathrm{HE}}$ & 0.39 & 0.41 & 0.44 & 0.94 & 0.79 & 0.80 & 0.03 & -0.02 & 0.05 & - & & \\
\hline$A R W_{D E}$ & 0.37 & 0.60 & 0.50 & 0.79 & 0.95 & 0.83 & 0.07 & 0.03 & 0.11 & 0.79 & - & \\
\hline$A R W_{D D}$ & 0.45 & 0.60 & 0.65 & 0.79 & 0.81 & 0.92 & 0.16 & 0.09 & 0.16 & 0.79 & 0.88 & - \\
\hline
\end{tabular}


tree were significant $(p>0.05$; Fig. 4$)$. The results were alike with the earlywood and the latewood width characteristics (not shown). Accordingly, soil depth was found to have no significant effect on growth variation in this site.

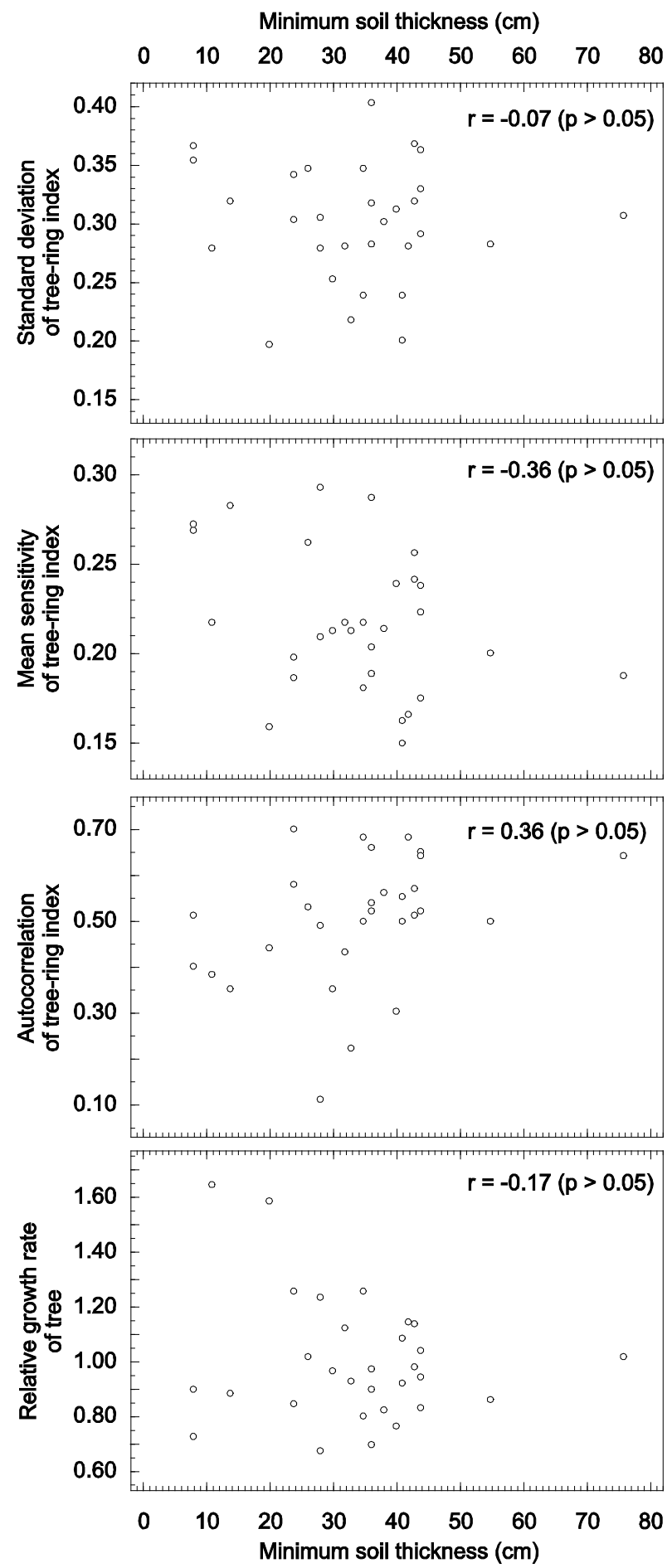

Fig. 4. Relationships between growth variability of annual ring width indices (standard deviation, mean sensitivity, autocorrelation), relative growth rate of each tree and minimum soil thickness around each tree, as described by Pearson correlation coefficients (r).

\section{Tree-ring width and climatic relationships}

The response values between the tree-ring data and the monthly climate variables revealed that oak growth was especially limited by June and July rainfall in all vigour classes based on the data from 1894-2004 $(\mathrm{p}<0.05$; Fig. 5). This association was positive and common to latewood and annual ring width in all vigour classes. Response of declining oak differed from other vigour classes in that May temperature had a positive effect on latewood formation and similarly on annual ring width. Earlywood width was less evidently controlled by the climate, only the declining oaks showing an exceptionally positive response to March precipitation. On the other hand, the majority of winter and spring month temperatures had positively affected earlywood formation, but the relationships were insignificant on monthly scale. On seasonal scale, we found that warmer winter and spring benefitted the earlywood dimension significantly, while the latewood was sensitive to summer rainfall $(\mathrm{p}<0.05$; Table 3$)$.

\section{DISCUSSION}

\section{Specifics of oak decline in Tammisto}

The cross-dating results showed that Tammisto oaks have died mostly during 2005-2007 or even before that time, as the last rings were unidentifiable in some samples. The causes cannot be associated with these years rigorously because dieback can be a decade-long process and death might be lagging behind the timing of the decline-inducing factors (Cherubini et al., 2002; Drobyshev et al., 2007b; Andersson et al., 2011). The pre-mortem growth reduction of the declining and dead trees was illustrated to have occurred already from the mid-1990s (Fig. 2). A similar degradation pattern has been identified earlier in the Framnäs oak site in south-western Finland (Helama et al., in prep.) and in the Annala Park in Helsinki where an abrupt oak growth reduction appeared

Table 3. Pearson correlation coefficients between the residual chronologies (earlywood width (EW), latewood width $(L W)$, total annual ring width (ARW) of healthy (HE), declining (DE) dead (DD) oaks) and weather characteristics of four seasons from the previous year (small letters) until the current year (capital letters) during the period 18942004. Statistically significant relationships $(p<0.05)$ are in bold.

\begin{tabular}{l|rrrr|rrrr}
\hline & \multicolumn{4}{|c|}{ Temperature } & \multicolumn{4}{c}{ Precipitation } \\
\cline { 2 - 9 } & son & dJF & MAM & JJA & son & dJF & MAM & JJA \\
\hline EW $_{\text {HE }}$ & 0.06 & $\mathbf{0 . 3 3}$ & $\mathbf{0 . 3 4}$ & 0.08 & $\mathbf{0 . 1 9}$ & 0.01 & 0.00 & 0.11 \\
EW $_{\text {DE }}$ & 0.00 & 0.18 & $\mathbf{0 . 2 1}$ & -0.07 & 0.07 & -0.02 & 0.18 & $\mathbf{0 . 2 2}$ \\
EW $_{\text {DD }}$ & 0.01 & $\mathbf{0 . 2 0}$ & $\mathbf{0 . 2 0}$ & -0.08 & 0.15 & 0.00 & -0.03 & 0.15 \\
LW $_{H E}$ & -0.02 & 0.07 & $\mathbf{0 . 2 0}$ & -0.10 & 0.03 & 0.08 & 0.01 & $\mathbf{0 . 4 6}$ \\
LW $_{\text {DE }}$ & -0.07 & 0.09 & 0.17 & -0.15 & 0.03 & 0.09 & 0.01 & $\mathbf{0 . 5 5}$ \\
LW $_{D D}$ & -0.03 & 0.06 & 0.18 & -0.14 & 0.03 & 0.05 & 0.07 & $\mathbf{0 . 4 7}$ \\
ARW $_{\text {HE }}$ & 0.01 & 0.09 & $\mathbf{0 . 2 6}$ & -0.09 & 0.05 & 0.08 & -0.01 & $\mathbf{0 . 4 2}$ \\
ARW $_{D E}$ & -0.06 & 0.12 & $\mathbf{0 . 2 1}$ & -0.13 & 0.06 & 0.05 & 0.06 & $\mathbf{0 . 5 3}$ \\
ARW & -0.02 & 0.15 & $\mathbf{0 . 2 5}$ & -0.13 & 0.08 & 0.06 & 0.00 & $\mathbf{0 . 4 4}$ \\
\hline
\end{tabular}




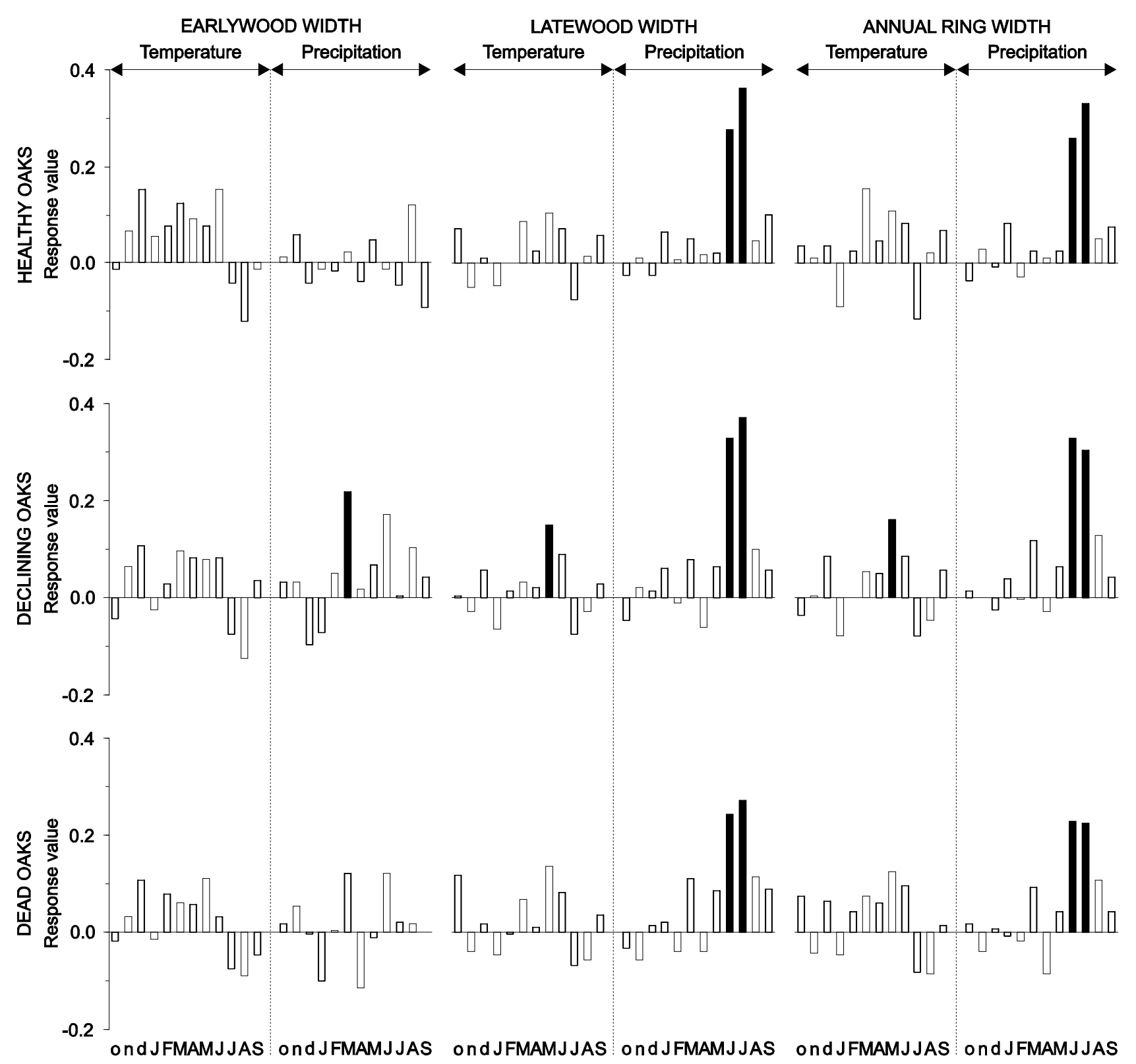

Fig. 5. Response values between the nine chronologies and the monthly meteorological variables from the previous (small letters) and current years (capital letters) during the period 1894-2004. Statistically significant relationships $(p<0.05)$ are indicated as filled bars.

some years later, from 2002 to 2003 (Helama et al., 2009). Thus, it seems to be a common feature of the oaks growing at the northern distributional limit in Finland.

Latewood width was more relevant in determining annual ring width than earlywood width (Table 2), like it has been demonstrated before as well (Doležal et al., 2010; Matisons and Brūmelis, 2012). Comparing our latewood and annual ring width chronologies and the corresponding cambial age growth patterns, the healthy oaks showed better long-term growth than the declining and the dead trees (Figs. 2 and 3). It was further shown that the relative growth rate was not related to soil thick- ness (Fig. 4). The better long-term growth may thus be related to some long-term stresses, such as inter-tree competition (Dobbertin, 2005; Rozas and García González, 2012) as the healthy oaks have recovered from the growth descent supposedly due to their favoured status in the stand hierarchy. Better radial growth in the healthy vigour class over the entire lifespan has been observed previously in other Finnish oak sites as well (Helama et al., 2009; Helama et al., in prep.).

Furthermore, the aforementioned study conducted in an urban park in Helsinki has shown that a shallow soil layer can cause additional environmental stress on tree 
growth. Conversely, we found that soil depth has no significant effect on growth variation in the concerned site (Fig. 4). Supposedly, soil conditions are equally poor on this sporadically exposed bedrock and the trees have ceased to resist to the water stress during the droughts.

Insect pests and pathogenic fungi can contribute to dieback as well (Hartmann et al., 1989; Führer, 1998; Siwecki and Ufnalski, 1998; Jung et al., 2000; Thomas et al., 2002). For example, defoliation by insects leads to extensive losses of photosynthates and depletion of carbohydrate reserves, root pathogens of Phytophthora spp. can destruct the fine root system and, in a combined effect with severe drought, threaten the health of trees. Moreover, root pathogens can decrease the ability of host trees to cope with drought and stop cambial activity like it has shown on spruces in the Eastern Alps (Gori et al., 2013). At our site we did not examine the biotic factors at all, thus their contribution in the analysed dieback cannot be discarded. On the other hand, no single pathogen or insect can cause oak decline on a large scale (Siwecki and Ufnalski, 1998), but oak forest decline has reported widely all over southern Finland recently (Ympäristöraportoinnin asiantuntijatyöryhmä, 2004; Holopainen et al., 2006; Helama et al., 2009). Thus, some disease could have contributed to the decline in Tammisto but most probably the weakening and dieback were triggered by a common large-scale factor (e.g. climate).

\section{Summer precipitation signal}

As growth was mostly controlled by summer precipitation (Fig. 5; Table 3) in all vigour classes, the narrow tree rings can be coupled with dry growing seasons and poor plant-water relations overall (Thomas and Hartmann, 1998). Summer droughts have been suggested as a contributing decline factor of oak in Poland (Siwecki and Ufnalski, 1998), in combination with exceptional winter frosts in Great Britain (Gibbs and Greig, 1997) and Germany (Hartmann et al., 1989). The geographically closest study to Finland derives from southern Sweden, where Drobyshev et al. (2007b) have suggested that the peak in oak mortality around the year 2000 was triggered by the spring and summer drought that occurred already in 1992. Another study from south-eastern Sweden has shown pronounced peaks in oak mortality in 2004 and 2006 with reduced growth after a severe drought in 1992, too (Andersson et al., 2011). June and July 1992 were exceptionally dry in Helsinki as well, in addition to several other summers from the 1990s like: 1991, 1994, 1995, 1997 and 1999 (Fig. 6). In other words, it was the period when a pre-mortem growth reduction of the declining and dead trees was observed in our study site. The year 2003, with an exceptionally dry growing season throughout Europe (Fink et al., 2004) as well as in Finland (Silander and Järvinen, 2004), showed a negative peak in our tree-ring series for each vigour class (Fig. 2). The same happened in 2006, which the Finnish Meteorological Institute (2012) described as the hottest and driest growing season in the Helsinki-Vantaa station during the 1961-2006 period. Thus, these sequential droughts might have led to the dieback during 2005-2007. In addition to the 1990s, a more severe drought period was experienced in Finland during the period 1939-1942 (Hydrografinen toimisto, 1944, 1948; Kuusisto, 2003, 2004). An increment drop in the 1940 and 1941 in the tree-ring chronologies was observable in every vigour class but the growth reduction did not continue (Fig. 2). This can be related to the physiologically younger tree age recovering the former status easier. In addition, the young oak tap-root is known as well-defined (Jones, 1959) and may better reach the lowered groundwater level.

Our dendroclimatic findings (Fig. 5) are supported by the earlier studies which have revealed a positive response of oak growth to summer precipitation in Finland (Helama et al., 2009; Hilasvuori and Berninger, 2010) as well as in Sweden (Drobyshev et al., 2008). This kind of relationship has been known for long (Stewart, 1913) and has been described for pedunculate oak widely around Europe recently. For example in the Baltic countries, June rainfall has the strongest positive influence on tree growth in Estonia (Läänelaid et al., 2008), August rainfall in Latvia (Matisons et al., 2012), and moist summers in the well-drained sites in Lithuania (Ruseckas, 2006). Also, farther east in the middle Volga region in Russia, a positive growth influence of spring-summer precipitation has been observed (Askeyev et al., 2005). According to Cedro (2007) as well as Bronisz et al. (2012) oak growth in Poland is dominated by summer precipitation while high temperature has negative influence. Poor oak increment is mainly ascribed to the water deficit during the early summer in the Czech Republic (Doležal et al., 2010) and in Germany (Friedrichs et al., 2009; Scharn-
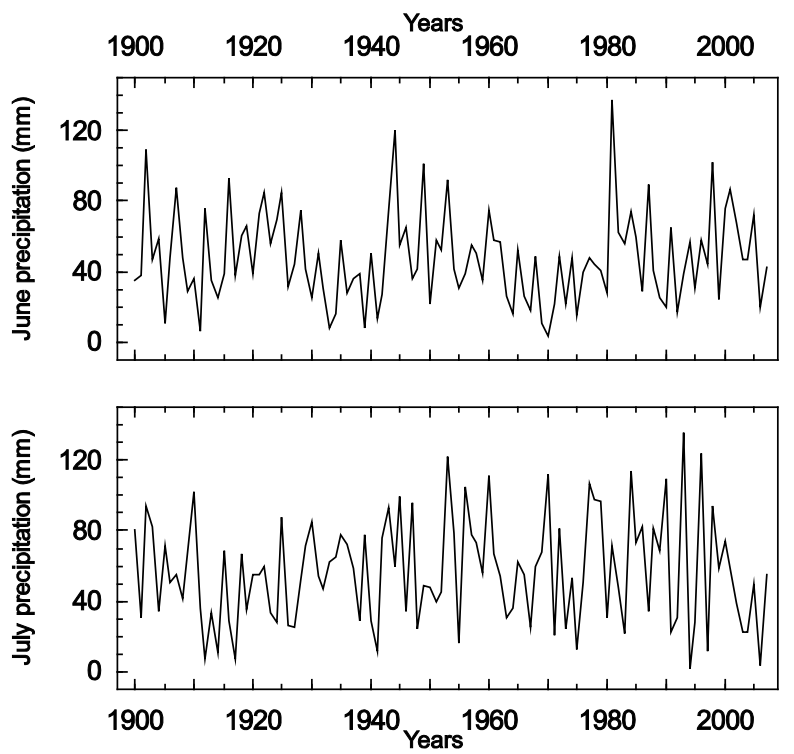

Fig. 6. Records of June and July precipitation sums from the Helsinki Kaisaniemi weather station. 
weber et al., 2011; Zang et al., 2012). Oak studies in the British Isles have shown that high rainfall during the growing season and high temperature during the early summer promote growth (Pilcher and Gray, 1982; Bridge et al., 1996). An enhancing effect of precipitation is widely observed in the Mediterranean environments (Santini et al., 1994; Tessier et al., 1994; Čufar et al., 2008) and the Atlantic Spain (Rozas, 2001, 2005), where high precipitation creates favourable and high temperature unfavourable growth conditions during the summer period. On the other hand, water excess can be limiting for growth and is triggering forest dieback in rainy temperate deciduous forest (Rozas and García González, 2012). Anyway, the importance of summer precipitation for oak tree-ring width is evident across Europe.

\section{Relationships to winter and spring conditions}

On the seasonal scale, tree-rings and especially earlywood widths were positively correlated with spring (March-May) temperature in every vigour class (Table 3). On a monthly scale, only the declining oaks showed a positive response to May temperature (Fig. 5). Earlywood width was controlled by winter (December-February) average temperature as well (Table 3), which means that mild rather than cool winters are more favourable to earlywood formation. As this part of the tree-ring involves water-conducting vessels for trees, the timing of ground melting and ground water accessibility is relevant. Doležal et al. (2010) have associated earlywood growth with previous autumn and winter temperatures in the White Carpathians in the Czech Republic. Vessel lumen area, another earlywood characteristic, shows also the highest positive correlations with temperatures from winter and spring months in Latvia (Matisons and Brūmelis, 2012).

Even if oak earlywood vessels enlarge in a short time in spring, between the bud break and the leaf expansion (Sass-Klaassen et al., 2011), the process can depend on the previous year's latewood (Nola, 1996). Moreover, according to Kitin et al. (1999) in ring-porous hardwood earlywood vessel elements most probably originate from the overwintered cambial derivatives. Nola (1996), García González and Eckstein (2003) have demonstrated a higher correlation between the current year's earlywood and the preceding year's latewood width than the same year's corresponding portions. Based on our study we can admit a similar relationship: the correlation coefficient between earlywood width of the current year and the latewood width of the previous year were $0.62,0.48$, and 0.50 in the healthy, declining and dead oaks, respectively. The similarity characteristics between the latewood and earlywood widths of the same year were $0.25,0.41$ and 0.39 , respectively (Table 2). Thus, the healthy trees showed the strongest relationship, which may refer to stronger biological dependence instead of environmental stress. The reasons behind that phenomenon were beyond the aim of this study and should be analysed in more detail in the future.

At the same time, the annual ring width showed no significant relationships to temperature during the deep dormancy period (Fig. 5; Table 3). Thus, frost damages, which can generate bark necrosis and initiate decline, seem not to be associated with mortality at our site, as it has been found in southern Sweden (Barklund and Wahlström, 1998). Moreover, previous study from Finland has shown significant negative correlation between tree-ring growth and winter temperatures, which is explained through permanent snow-cover appearance during below zero temperatures and thus better root insulation (Helama et al., 2009). Alike relationships were not found in our study site. Exceptionally, the declining oak earlywood showed a positive response to March precipitation. Most probably this is random coincidental and not related to root insulation by the snowpack because the snow cover forms over several months and other dormancy months did not show a significant correlation between precipitation and the increment.

\section{CONCLUSIONS}

The results support the previous oak decline study from Finland (Helama et al., 2009) which showed drought incited oak decline on the shallow soil. The comparison of oak vigour classes (the living, the declining, and the dead) in the Tammisto forest revealed no significant differences in age, mean ring width, mean sensitivity, relative growth rate, nor soil depth around the tree, even though differences in the foliage and vital capacity were visible. We can assume the soil conditions are equally poor on the sporadically exposed bedrock. The dendroclimatic analysis showed a similarly positive 'summer response' meaning the summer droughts had an inhibiting effect on the oaks. Water stress is equal to oaks in all vigour classes, obviously due to the shallow soil. Apparently, the sequential droughts during the preceding decade incited the dieback of the declining and the dead trees during 2005-2007. Thus, there appears to be a time lag between the mortality-inducing factors and actual death. Our results differ from the previous study in a lack of clear negative climate 'winter response'. On the seasonal scale, we can admit a favourable spring warmth effect on both earlywood and total annual ring growth and a positive effect of mild winter on earlywood formation.

\section{ACKNOWLEDGEMENTS}

The field work was carried out under the license from the City of Vantaa (Dno YM 2930/2008/516). The research was supported by the European Social Fund's Doctoral Studies and Internationalisation Programme DoRa, which is carried out by Foundation Archimedes, by the Estonian State Target Foundation 
(\#SF0180049s09), and by the Academy of Finland (\#251441). We thank the anonymous reviewers for their critical comments on the manuscript.

\section{REFERENCES}

Allen CD, Macalady AK, Chenchouni H, Bachelet D, McDowell N, Vennetier M, Kitzberger T, Rigling A, Breshears DD, Hogg EH, Gonzalez P, Fensham R, Zhang Z, Castro J, Demidova N, Lim JH, Allard G, Running SW, Semerci A and Cobb N, 2010. A global overview of drought and heat-induced tree mortality reveals emerging climate change risks for forests. Forest Ecology and Management 259(4): 660-684, DOI 10.1016/j.foreco.2009.09.001.

Andersson M, Milberg P and Bergman K-O, 2011. Low pre-death growth rates of oak (Quercus robur L.) - Is oak death a long-term process induced by dry years? Annals of Forest Science 68(1): 159-168, DOI 10.1007/s13595-011-0017-y.

Aniol RW, 1983. Tree-ring analysis using CATRAS. Dendrochronologia 1: 45-53.

Arend M, Kuster T, Günthardt-Goerg MS and Dobbertin M, 2011. Provenance-specific growth responses to drought and air warming in three European oak species (Quercus robur, Q. petraea and $Q$. pubescens). Tree Physiology 31(3): 287-297, DOI 10.1093/treephys/tpr004.

Askeyev OV, Tischin D, Sparks TH and Askeyev IV, 2005. The effect of climate on the phenology, acorn crop and radial increment of pedunculate oak (Quercus robur) in the middle Volga region, Tatarstan, Russia. International Journal of Biometeorology 49(4): 262-266, DOI 10.1007/s00484-004-0233-3.

Axelrod DI, 1983. Biogeography of oaks in the Arcto-Tertiary province. Annals of the Missouri Botanical Garden 70(4): 629-657, DOI $10.2307 / 2398982$.

Barklund P and Wahlström K, 1998. Death of oaks in Sweden since 1987. In: Cech TL, Hartman G, Tomiczek C, eds., Diseaselenvironment interactions in forest decline. Proceedings of a workshop of the working party Disease/Environment Interactions in Forest Decline IUFRO 7.02.06, 16-21 March 1998. Federal Forest Research Centre, Vienna, Austria: 193.

Bigler C and Bugmann H, 2004. Predicting the time of tree death using dendrochronological data. Ecological Applications 14(3): 902-914, DOI 10.1890/03-5011.

Biondi F and Waikul K, 2004. DENDROCLIM2002: A C++ program for statistical calibration of climate signals in tree-ring chronologies. Computers \& Geosciences 30(3): 303-311, DOI 10.1016/j.cageo.2003.11.004.

Bridge MC, Gasson PE and Cutler DF, 1996. Dendroclimatological observations on trees at Kew and Wakehurst Place: event and pointer years. Forestry 69(3): 263-269, DOI 10.1093/forestry/69.3.263.

Briffa KR and Cook ER, 1990. Methods of response function analyses. In: Cook ER and Kairiukstis LA, eds., Methods of dendrochronology: Applications in the environmental sciences. International Institute for Applied Systems Analysis/Kluwer Academic Publishers, Dordrecht: 240-247.

Briffa KR, Jones PD, Bartholin TS, Eckstein D, Schweingruber FH, Karlén W, Zetterberg P and Eronen M, 1992. Fennoscandian summers from $\mathrm{AD} 500$ : temperature changes on short and long timescales. Climate Dynamics 7(3): 111-119, DOI 10.1007/BF00211153.

Briffa KR and Melvin TM, 2011. A closer look at regional curve standardization of tree-ring records: justification of the need, a warning of some pitfalls, and suggested improvements in its application. In: Hughes MK, Swetnam TW, Diaz HF, eds., Dendroclimatology: progress and prospects. Springer, Dordrecht: 113-145.

Bronisz A, Bijak S, Bronisz K and Zasada M, 2012. Climate influence on radial increment of oak (Quercus sp.) in central Poland. Geochronometria 39(4): 276-284, DOI 10.2478/s13386-012-0011-7.

Catton HA, St George S and Remphrey WR, 2007. An evaluation of bur oak (Quercus macrocarpa) decline in the urban forest of Winni- peg, Manitoba, Canada. Arboriculture \& Urban Forestry 33(1): 22-30.

Cedro A, 2007. Tree-ring chronologies of downy oak (Quercus pubescens $)$, pedunculate oak $(Q$. robur $)$ and sessile oak $(Q$. petraea $)$ in the Bielinek Nature Reserve: Comparison of the climatic determinants of tree-ring width. Geochronometria 26: 39-45, DOI 10.2478/v10003-007-0005-2.

Cherubini P, Fontana G, Rigling D, Dobbertin M, Brang P and Innes JL, 2002. Tree-life history prior to death: two fungal root pathogens affect tree-ring growth differently. Journal of Ecology 90(5): 839850, DOI 10.1046/j.1365-2745.2002.00715.x.

Cook ER, 1985. A time series analysis approach to tree ring standardization. PhD Dissertation, University of Arizona: 171pp.

Cook ER, 1987. The decomposition of tree-ring series for environmental studies. Tree-Ring Bulletin 47: 37-59.

Cook ER and Peters K, 1981. The smoothing spline: a new approach to standardizing forest interior tree-ring width series for dendroclimatic studies. Tree-Ring Bulletin 41: 45-53.

Čufar K, De Luis M, Zupančič M and Eckstein D, 2008. A 548-year tree-ring chronology of oak (Quercus spp.) for southeast Slovenia and its significance as dating tool and climate archive. Tree-Ring Research 64(1): 3-15, DOI 10.3959/2007-12.1.

Dahl E, 1998. The phytogeography of Northern Europe: British Isles, Fennoscandia and adjacent areas. Cambridge University Press, Cambridge: 297pp, DOI 10.1017/CBO9780511565182.

Dickson RE and Tomlinson PT, 1996. Oak growth, development and carbon metabolism in response to water stress. Annals of Forest Science 53(2-3): 181-196, DOI 10.1051/forest:19960202.

Dobbertin M, 2005. Tree growth as indicator of tree vitality and of tree reaction to environmental stress: a review. European Journal of Forest Research 124(4): 319-333, DOI 10.1007/s10342-005-00853.

Doležal J, Mazůrek P and Klimešová J, 2010. Oak decline in southern Moravia: the association between climate change and early and late wood formation in oaks. Preslia 82(3): 289-306.

Drobyshev I, Anderson S and Sonesson K, 2007a. Crown condition dynamics of oak in southern Sweden 1988-1999. Environmental Monitoring and Assessment 134(1-3): 199-210, DOI 10.1007/s10661-007-9610-9.

Drobyshev I, Linderson H and Sonesson K, 2007b. Temporal mortality pattern of pedunculate oaks in southern Sweden. Dendrochronologia 24(2-3): 97-108, DOI 10.1016/j.dendro.2006.10.004.

Drobyshev I, Niklasson M, Eggertsson O, Linderson H and Sonesson K, 2008. Influence of annual weather on growth of pedunculate oak in southern Sweden. Annals of Forest Science 65(5): 512, DOI 10.1051/forest:2008033.

EUFORGEN, 2009. Distribution map of pedunculate oak (Quercus robur). WEB site: www.euforgen.org. Accessed 2013 March 25.

Faber-Langendoen D and Tester JR, 1993. Oak mortality in sand savannas following drought in East-Central Minnesota. Bulletin of the Torrey Botanical Club 120(3): 248-256, DOI 10.2307/2996989.

Fink AH, Brücher T, Krüger A, Leckebusch GC, Pinto JG and Ulbrich U, 2004. The 2003 European summer heatwaves and drought synoptic diagnosis and impacts. Weather 59(8): 209-216, DOI 10.1256/wea.73.04.

Finnish Meteorological Institute, 2012. Terminen kasvukausi 2006 (The thermal growing season 2006). WEB site: http://ilmatieteenlaitos.fi/kasvukausi-2006. Accessed 2013 January 22 (in Finnish).

Friedrichs DA, Büntgen U, Frank DC, Esper J, Neuwirth B and Löffler J, 2009. Complex climate controls on 20th century oak growth in Central-West Germany. Tree Physiology 29(1): 39-51, DOI $10.1093 /$ treephys/tpn003.

Fritts HC, 1976. Tree Rings and Climate. Academic Press, London: $567 \mathrm{pp}$.

Führer E, 1998. Oak decline in central Europe: a synopsis of hypotheses. In: McManus ML and Liebhold AM, eds., Proceedings: population dynamics, impacts, and integrated management of forest defoliating insects. USDA Forest Service, General Technical Report NE-247: 7-24. 
García González I and Eckstein D, 2003. Climatic signal of earlywood vessels of oak on a maritime site. Tree Physiology 23(7): 497-504, DOI 10.1093/treephys/23.7.497.

Gibbs JN and Greig BJW, 1997. Biotic and abiotic factors affecting the dying back of pedunculate oak Quercus robur L. Forestry 70(4): 399-406, DOI 10.1093/forestry/70.4.399.

Gori Y, Cherubini P, Camin F and La Porta N, 2013. Fungal root pathogen (Heterobasidion parviporum) increases drought stress in Norway spruce stand at low elevation in the Alps. European Journal of Forest Research 132(4): 607-619, DOI 10.1007/s10342-0130698-x.

Hartmann G, Blank R and Lewark S, 1989. Eichensterben in Norddeutschland. Verbreitung, Schadbilder, mögliche Ursachen (Oak decline in Northern Germany. Distribution, symptoms, probable causes). Forst und Holz 44(18): 475-487 (in German with English summary).

Helama S, Läänelaid A, Raisio J and Tuomenvirta H, 2009. Oak decline in Helsinki portrayed by tree-rings, climate and soil data. Plant and Soil 319(1-2): 163-174, DOI 10.1007/s11104-008-9858-z.

Helama S, Läänelaid A, Raisio J and Tuomenvirta H, 2012. Mortality of urban pines in Helsinki explored using tree ring and climate records. Trees - Structure and Function 26(2): 353-362, DOI 10.1007/s00468-011-0597-z.

Hilasvuori E and Berninger F, 2010. Dependence of tree ring stable isotope abundances and ring width on climate in Finnish oak. Tree Physiology 30(5): 636-647, DOI 10.1093/treephys/tpq019.

Holmes RL, 1983. Computer-assisted quality control in tree-ring dating and measurement. Tree-Ring Bulletin 43: 69-78.

Holopainen M, Leino O, Kämäri $\mathrm{H}$ and Talvitie M, 2006. Drought damage in the park forests of the city of Helsinki. Urban Forestry \& Urban Greening 4(2): 75-83, DOI 10.1016/j.ufug.2005.11.002.

Honkanen J, 2009. Tammiston luonnonsuojelualueen ja rauhoitettujen luontotyyppien hoito- ja käyttösuunnitelma 2010-2020 (Tammisto Nature Reserve and protected nature types conservation and landuse plan 2010-2020). Ympäristökeskus, Vantaan kaupunki: 12pp (in Finnish).

Hydrografinen toimisto, 1944. Vuosikirja 12 Arsbok 1937-1940 (Yearbook 1937-1940). Valtioneuvoston kirjapaino, Helsinki: 118pp (in Finnish and Swedish)

Hydrografinen toimisto, 1948. Vuosikirja 13 Arsbok 1941-1945 (Yearbook 1941-1945). Valtioneuvoston kirjapaino, Helsinki: 123pp (in Finnish and Swedish)

Jones EW, 1959. Biological flora of the British Isles: Quercus L. Journal of Ecology 47(1): 169-222.

Jönsson U, Jung T, Sonesson K and Rosengren U, 2005. Relationships between health of Quercus robur, occurrence of Phytophthora species and site conditions in southern Sweden. Plant Pathology 54(4): 502-511, DOI 10.1111/j.1365-3059.2005.01228.x.

Jung T, Blaschke H and Oßwald W, 2000. Involvement of soilborne Phytophthora species in Central European oak decline and the effect of site factors on the disease. Plant Pathology 49(6): 706-718, DOI 10.1046/j.1365-3059.2000.00521.x.

Kitin P, Funada R, Sano Y, Beeckman H and Ohtani J, 1999. Variations in the lengths of fusiform cambial cells and vessel elements in $\mathrm{Ka}$ lopanax pictus. Annals of Botany 84(5): 621-632, DOI 10.1006/anbo.1999.0957.

Kuusisto E, 2003. Paha kuivuus lisäsi jatkosodan ankeutta (Bad drought added to the Continuation War bleakness). Helsingin Sanomat 12.4.2003: C17 (in Finnish).

Kuusisto E, 2004. Kuvaus 1940-luvun poikkeuksellisesta kuivuudesta (A depiction of the exceptional dryness in the 1940s). In: Silander J and Järvinen A, eds., Vuosien 2002-2003 poikkeuksellisen kuivuuden vaikutukset (Effects of Severe Drought of 2002-2003). Suomen ympäristökeskus 731: 48 (in Finnish).

Läänelaid A, 2000. Five pine samples represent climate impact as well as eleven pines. University of Joensuu, Faculty of Forestry, Research Notes 108: 119-128.

Läänelaid A, Sohar K and Meikar T, 2008. Present state and chronology of oaks in an oak forest in Saaremaa Island, Estonia. Baltic Forestry 14(1): $34-43$.
Landmann $\mathrm{G}$ and Dreyer E, eds., 2006. Impacts of drought and heat on forest. Synthesis of available knowledge, with emphasis on the 2003 event in Europe. Annals of Forest Science 63(6): 567-568, DOI 10.1051/forest:2006062.

Li M-H, Cherubini P, Dobbertin M, Arend M, Xiao W-F and Rigling A, 2013. Responses of leaf nitrogen and mobile carbohydrates in different Quercus species/provenances to moderate climate changes. Plant Biology 15(SI1): 177-184, DOI 10.1111/j.14388677.2012.00579.x.

Manion PD, 1981. Tree disease concepts. Prentice Hall, Englewood Cliff, New Jersey: 399pp.

Matisons R and Brūmelis G, 2012. Influence of climate on tree-ring and earlywood vessel formation in Quercus robur in Latvia. Trees Structure and Function 26(4): 1251-1266, DOI 10.1007/s00468012-0701-z.

Matisons R, Elferts D and Brūmelis G, 2012. Changes in climatic signals of English oak tree-ring width and cross-section area of earlywood vessels in Latvia during the period 1900-2009. Forest Ecology and Management 279: 34-44, DOI 10.1016/j.foreco.2012.05.029.

McCracken FI, 1985. Oak decline and mortality in the South. In: Proceedings, Third Symposion of Southeastern Hardwoods, Atlanta, 16-17 April 1985. USDA Forest Service, Dothan: 77-81.

Nola P, 1996. Climatic signal in earlywood and latewood of deciduous oaks from northern Italy. In: Dean JS, Meko DM, Swetnam TW, eds., Tree Rings, Environment and Humanity: Proceedings of the international conference, Radiocarbon. Department of Geosciences, University of Arizona, Tucson: 249-258.

Pedersen BS, 1998. The role of stress in the mortality of midwestern oaks as indicated by growth prior to death. Ecology 79(1): 79-93, DOI $10.2307 / 176866$.

Peñuelas J, Lloret F and Montoya R, 2001. Severe drought effects on Mediterranean woody flora in Spain. Forest Science 47(2): 214218.

Pilcher JR and Gray B, 1982. The relationships between oak tree growth and climate in Britain. Journal of Ecology 70(1): 297-304, DOI $10.2307 / 2259880$.

Rainio RJ, 1977. Tammen levinneisyydestä läntisellä Uudellamaalla ja Turunmaan itäisemmissä osissa (On the distribution of oak (Quercus robur) in the southwestern-most parts of Finland). Silva Fennica 11(2): 127-135 (in Finnish with English summary).

Repo T, Mononen K, Alvila L, Pakkanen TT and Hänninen H, 2008 Cold acclimation of pedunculate oak (Quercus robur L.) at its northernmost distribution range. Environmental and Experimental Botany 63(1-3): 59-70, DOI 10.1016/j. envexpbot.2007.10.023.

Rinn F, 2003. TSAP-Win. Time series analysis and presentation for dendrochronology and related applications. Version 0.53 for Microsoft Windows. User Reference. Rinntech Heidelberg, Heidelberg: $91 \mathrm{pp}$.

Rozas V, 2001. Detecting the impact of climate and disturbances on tree-rings of Fagus sylvatica L. and Quercus robur L. in a lowland forest in Cantabria, Northern Spain. Annals of Forest Science 58(3): 237-251, DOI 10.1051/forest:2001123.

Rozas V, 2005. Dendrochronology of pedunculate oak (Ouercus robur L.) in an old-growth pollarded woodland in northern Spain: treering growth responses to climate. Annals of Forest Science 62(3): 209-218, DOI 10.1051/forest:2005012.

Rozas V and García González I, 2012. Too wet for oaks? Inter-tree competition and recent persistent wetness predispose oaks to rainfall-induced dieback in Atlantic rainy forest. Global and Planetary Change 94-95: 62-71, DOI 10.1016/j.gloplacha.2012.07.004.

Ruseckas J, 2006. Impact of climatic fluctuations on radial increment of English oak (Quercus robur L.). Ecologija 1: 16-24.

Santini A, Bottacci A and Gellini R, 1994. Preliminary dendroecological survey on pedunculate oak (Quercus robur L) stands in Tuscany (Italy). Annals of Forest Science 51(1): 1-10, DOI 10.1051/forest:19940101.

Sass-Klaassen U, Sabajo CR and den Ouden J, 2011. Vessel formation in relation to leaf phenology in pedunculate oak and European ash. Dendrochronologia $\quad$ 29(3): $\quad 171-175, \quad$ DOI 10.1016/j.dendro.2011.01.002 
Scharnweber T, Manthey M, Criegee C, Bauwe A, Schröder C and Wilmking M, 2011. Drought matters - declining precipitation influences growth of Fagus sylvatica L. and Quercus robur L. in north-eastern Germany. Forest Ecology and Management 262(6): 947-961, DOI 10.1016/j.foreco.2011.05.026.

Schweingruber FH, 2007. Wood structure and environment. SpringerVerlag, Berlin: 279pp.

Silander J and Järvinen EA, eds., 2004. Vuosien 2002-2003 poikkeuksellisen kuivuuden vaikutukset (Effects of Severe Drought of 20022003). Suomen ympäristö 731: 79pp (in Finnish with English abstract).

Siwecki R and Ufnalski K, 1998. Review of oak stand decline with special reference to the role of drought in Poland. European Journal of Forest Pathology 28(2): 99-112, DOI 10.1111/j.14390329.1998.tb01171.x.

Sonesson K, 1999. Oak decline in southern Sweden. Scandinavian Journal of Forest Research 14(4): 368-375, DOI 10.1080/02827589950152692.

Starkey DA and Oak SW, 1989. Site factors and stand conditions associated with oak decline in southern upland hardwood forests. In: Rink G and Budelsky CA, eds., Proceedings of the Seventh Central Hardwoods Forest Conference, Carbondale, IL, 5-8 March 1989. USDA Forest Service, General Technical Report NC-132: 95-102.

Starkey DA, Oak SW, Ryan GW, Tainter FH, Redmond C and Brown HD, 1989. Evaluation of oak decline areas in the south. USDA Forest Service, Protection Report R8-PR 17: 39pp

Starkey DA, Oliveria F, Mangini A and Mielke M, 2004. Oak decline and red oak borer in the interior highlands of Arkansas and Missouri: natural phenomena, severe occurrences. In: Spetich MA, ed., Upland oak ecology symposium: history, current conditions, and sustainability. USDA Forest Service, General Technical Report SRS-73: 217-222.

Stewart MN, 1913. Relation of precipitation to tree growth. Monthly Weather Review 41(9): 1287-1297.

Tesfa TK, Tarboton DG, Chandler DG and McNamara JP, 2009. Modeling soil depth from topographic and land cover attributes. Water Resources Research 45(10): W10438, DOI 10.1029/2008WR007474.

Tessier L, Nola P and Serre-Bachet F, 1994. Deciduous Quercus in the Mediterranean region: tree-ring/climate relationships. New Phytologist 126(2): 355-367, DOI 10.1111/j.1469-8137.1994.tb03955.x.

Thomas FM and Hartmann G, 1998. The rooting patterns and soil water relations of healthy and damaged stands of mature oak (Quercus robur L. and Quercus petraea [Matt.] Liebl.). Plant and Soil 203(1): 145-158, DOI 10.1023/A:1004305410905.

Thomas FM, Blank R and Hartmann G, 2002. Abiotic and biotic factors and their interactions as causes of oak decline in Central Europe. Forest Pathology 32(4-5): 277-307, DOI 10.1046/j.14390329.2002.00291.x.

Tuomenvirta H, 2004. Reliable estimation of climatic variations in Finland. Finnish Meteorological Institute Contributions 43: 1-79.

Wargo PM, 1996. Consequences of environmental stress on oak: predisposition to pathogens. Annals of Forest Science 53(2-3): 359368, DOI 10.1051/forest:19960218.

Ympäristöraportoinnin asiantuntijatyöryhmä, 2004. Helsingin kaupungin ympäristöraportti 2003 (Helsinki City environmental report 2003). Environment Centre, City of Helsinki, Helsinki: 46pp (in Finnish).

Zang C, Pretzsch H and Rothe A, 2012. Size-dependent responses to summer drought in Scots pine, Norway spruce and common oak. Trees - Structure and Function 26(2): 557-569, DOI 10.1007/s00468-011-0617-z. 